\title{
Quantifying mass balance processes on the Southern Patagonia Icefield
}

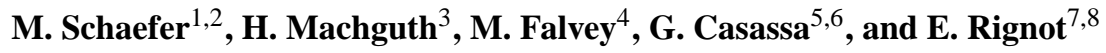 \\ ${ }^{1}$ Instituto de Ciencias Físicas y Matematicas, Facultad de Ciencias, Universidad Austral de Chile, Valdivia, Chile \\ ${ }^{2}$ Instituto de Ciencias Marinas y Limnológicas, Facultad de Ciencias, Universidad Austral de Chile, Valdivia, Chile \\ ${ }^{3}$ Arctic Technology Centre, Technical University of Denmark, Kgs. Lyngby, Denmark \\ ${ }^{4}$ Department of Geophysics, Universidad de Chile, Santiago, Chile \\ ${ }^{5}$ Geoestudios, Las Vertientes, San José de Maipo, Chile \\ ${ }^{6}$ Universidad de Magallanes, Punta Arenas, Chile \\ ${ }^{7}$ Jet Propulsion Laboratory, Pasadena, CA, USA \\ ${ }^{8}$ University of California, Department of Earth System Science, Irvine, CA, USA
}

Correspondence to: M. Schaefer (mschaefer@uach.cl)

Received: 9 April 2014 - Published in The Cryosphere Discuss.: 11 June 2014

Revised: 15 November 2014 - Accepted: 20 November 2014 - Published: 6 January 2015

\begin{abstract}
We present surface mass balance simulations of the Southern Patagonia Icefield (SPI) driven by downscaled reanalysis data. The simulations were evaluated and interpreted using geodetic mass balances, measured point balances and a complete velocity field of the icefield for spring 2004. The high measured accumulation of snow of up to $15.4 \mathrm{~m}$ w.e. $\mathrm{yr}^{-1}$ (meters water equivalent per year) as well as the high measured ablation of up to $11 \mathrm{~m} \mathrm{w.e.} \mathrm{yr}^{-1}$ is reproduced by the model. The overall modeled surface mass balance was positive and increasing during 1975-2011. Subtracting the surface mass balance from geodetic balances, calving fluxes were inferred. Mass losses of the SPI due to calving were strongly increasing from 1975-2000 to 20002011 and higher than losses due to surface melt. Calving fluxes were inferred for the individual glacier catchments and compared to fluxes estimated from velocity data. Measurements of ice thickness and flow velocities at the glaciers' front and spatially distributed accumulation measurements can help to reduce the uncertainties of the different terms in the mass balance of the Southern Patagonia Icefield.
\end{abstract}

\section{Introduction}

The Southern Patagonia Icefield (SPI, Fig. 1) is the largest ice mass in the Southern Hemisphere outside of Antarctica.
The great majority of its outlet glaciers have been retreating and thinning at high rates in recent decades (Rignot et al., 2003; Masiokas et al., 2009; López et al., 2010; Willis et al., 2012b; Davies and Glasser, 2012; White and Copland, 2013). Mass balance processes for most of the glaciers of the SPI, however, are poorly quantified, which makes it difficult to understand the reasons for the fast ice loss from the SPI. Increase in surface melt, decrease in accumulation or changes in the ice dynamics are possible candidates. Another explanation could be sub-glacial volcanic activity (Orihashi et al., 2004) which is supported by the fact that the SPI co-locates with four volcanoes of the Andean Austral Volcanic Zone (Stern, 2004, 2008).

Locally varying warming trends have been observed in southern South America in the last century with rates up to $0.028^{\circ} \mathrm{C} \mathrm{yr}^{-1}$ next to the Atlantic Ocean (Rosenblüth et al., 1995; Ibarzabal y Donangelo et al., 1996; Rasmussen et al., 2007; Falvey and Garreaud, 2009). Large interannual and inter-decadal variations of precipitation have been observed in Patagonia, although with no significant overall trends in the last century (Rosenblüth et al., 1995; Carrasco et al., 2002; Aravena and Luckman, 2009).

Prominent acceleration of the ice flow (and therefore ice losses due to calving) were detected at the Jorge Montt (Rivera et al., 2012a) and Upsala glaciers(Jaber et al., 2012; 


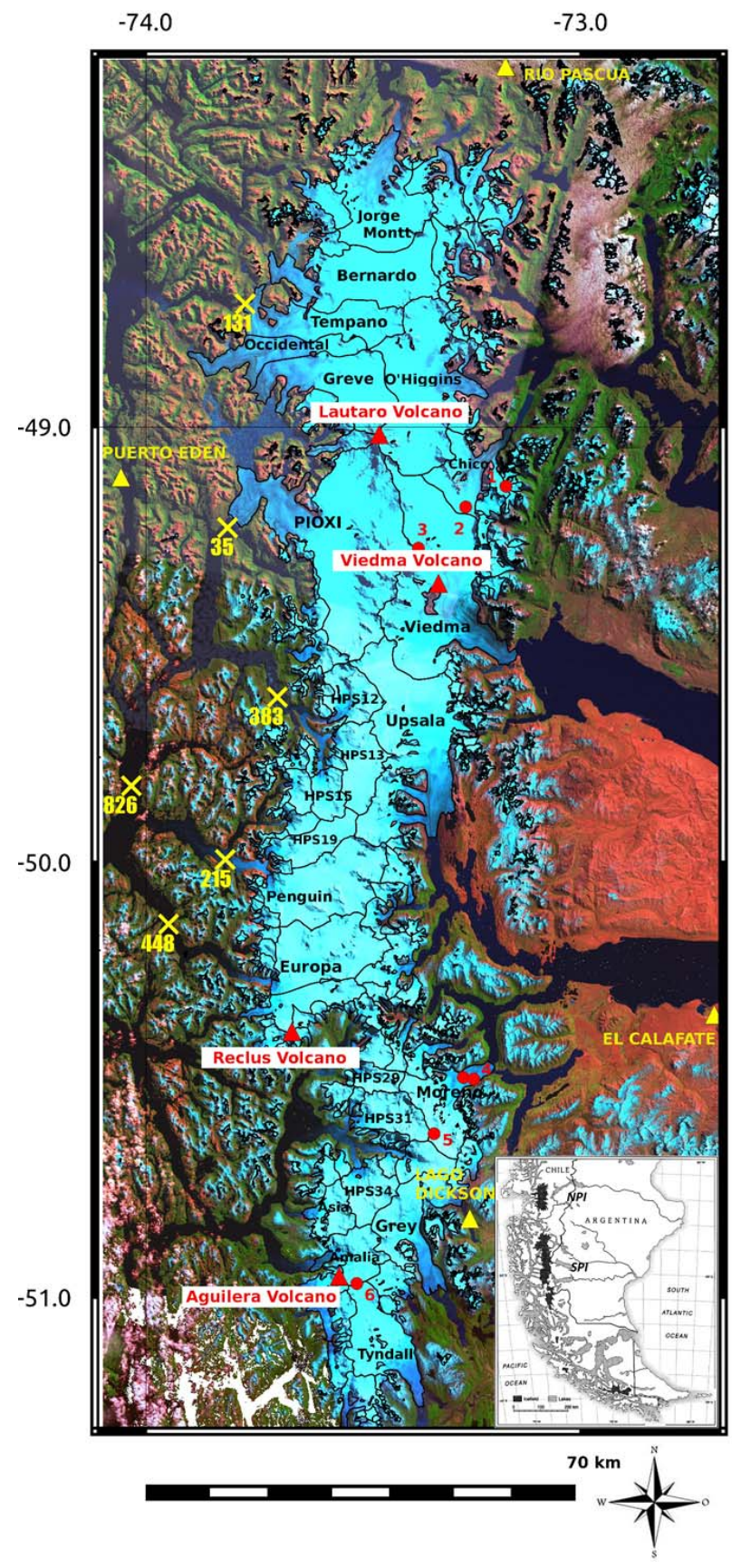

Figure 1. The Southern Patagonia Icefield (SPI): false color composite of Landsat ETM+ satellite image mosaic; names of examined glacier catchments in black; yellow triangles mark the positions of some of the meteorological stations that were used to validate the downscaling of the reanalysis data; red dots mark direct surface mass balance measurements on the SPI (1-6); the four active volcanoes that co-locate with the SPI are represented by red triangles. The yellow crosses with numbers mark individual measurements of fjord depth provided by the Chilean Navy Hydrographic and Oceanographic Service (SHOA). Inset: position of the SPI in southern South America.
Sakakibara et al., 2013). For both glaciers a fast retreat was observed together with the acceleration.

The surface mass balance was modeled for two glaciers of the SPI: Chico (Rivera, 2004) and Perito Moreno (Stuefer et al., 2007), both using degree-day models. For the period 1975-2001, Rivera (2004) obtained an average negative yearly surface mass balance of the Chico glacier, which showed high interannual variations and a slightly negative trend. Stuefer et al. (2007) obtained a near-zero cumulative glacier mass balance for the Perito Moreno glacier between 1973 and 2000, with the annual specific balances varying between +1 and $-1 \mathrm{~m}$ w.e.

A combined modeling approach was recently applied on the Northern Patagonia Icefield (NPI) (Schaefer et al., 2013): global meteorological data were downscaled using the regional climate model Weather Research and Forecasting and statistical downscaling techniques. These data were used to drive a surface mass balance model of intermediate complexity (Oerlemans, 2001; Machguth et al., 2009). An increase of accumulation was detected over the NPI during 19752011. The increased observed mass loss of the NPI in 2000 2011 (Willis et al., 2012a) as compared to 1975-2000 (Rignot et al., 2003) was explained by an increase of losses by calving.

In this paper, a similar methodology is applied to make first inferences of the components of the mass balance of the SPI as a whole and for its individual glacier catchments. We give a summary of the methods applied in Sect. 2. In Sect. 3 we present the results and discuss them; in Sect. 4 we draw the conclusions of our study.

\section{Methods}

To obtain realistic meteorological input data for the surface mass balance model in the modeling period 1975-2011, a downscaling procedure has been realized, which includes a number of steps (Schaefer et al., 2013). As a first step, version 3.2 of the Advanced Research Weather Research and Forecasting model (WRF model hereafter) was run for a 7year period from 2005 until 2011, using a nested computational grid (five-point relaxation zone between grids), with the inner grid having a spatial resolution of $5 \mathrm{~km}$ over an area of $675 \mathrm{~km} \times 425 \mathrm{~km}$ that includes both the NPI and SPI. The model was forced at its boundaries by NCEP-NCAR atmospheric reanalysis data (Kalnay et al., 1996), which consist of three-dimensional atmospheric fields on a $2.5^{\circ}$ resolution grid at $6 \mathrm{~h}$ intervals. The WRF model's output was saved at hourly intervals, which were used to yield the daily averages required by the surface mass balance model. To obtain downscaled meteorological data for the entire 1975-2011 period, statistical downscaling techniques were applied similar to the ones used to relate local climate observations to large-scale atmospheric parameters that are predicted by lowresolution global circulation models (Fowler et al., 2007). 

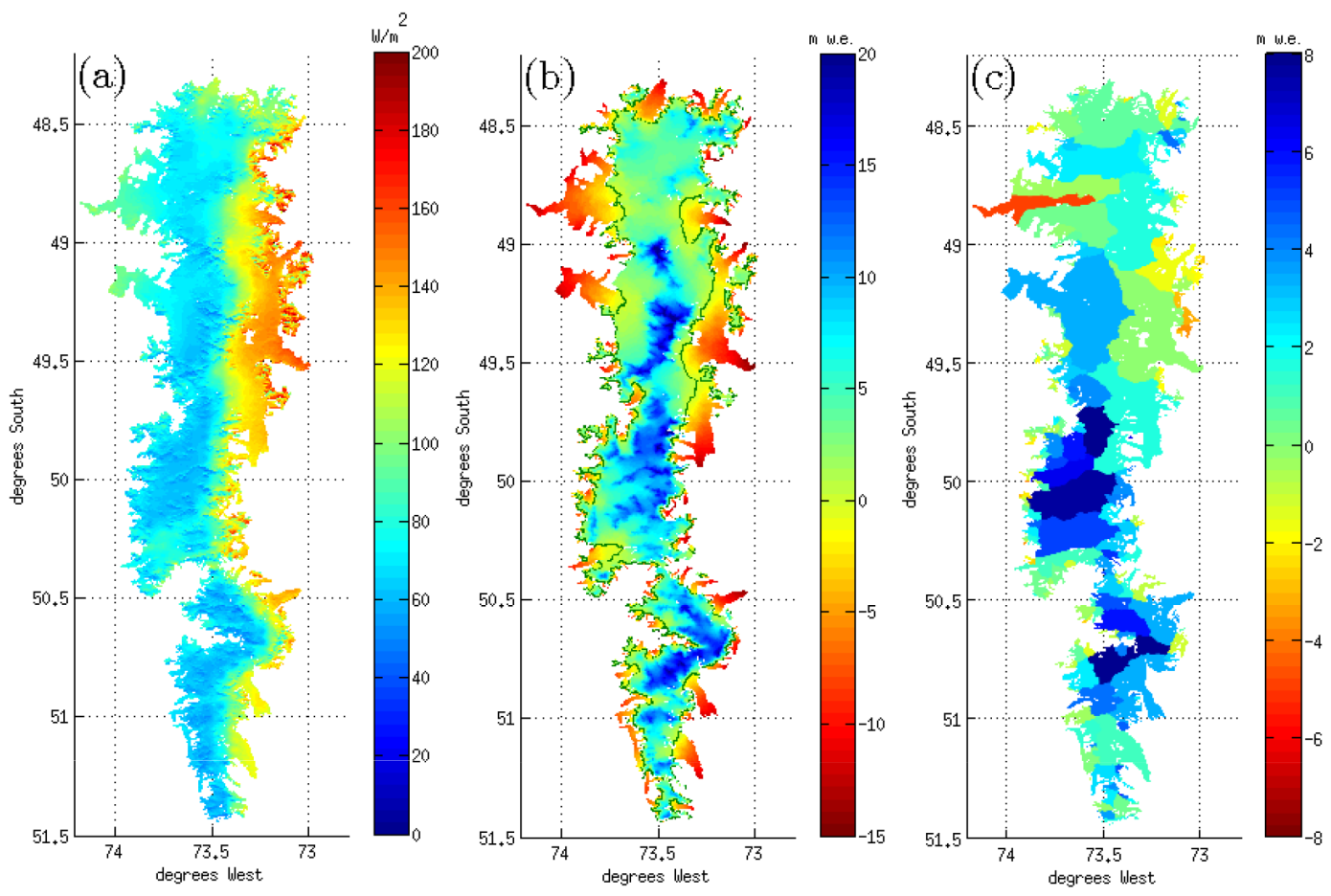

Figure 2. Maps of (a) downscaled incoming solar radiation over SPI; (b) annual surface mass balance of the SPI (green line denotes zero mass balance); (c) annual averaged glacier surface mass balance. All maps show averages of 1975-2011.

The basic assumption is that local variability (which in this case is simulated rather than observed) is to a large extent controlled by the overriding synoptic conditions, and that long-term changes in these synoptic conditions are the key drivers of long-term changes in local variables. The series of daily fields of precipitation, temperature and incoming shortwave radiation for the period 2005-2011 are modeled in terms of 11 predictors taken from the NCEP-NCAR reanalysis data at a grid point some $250 \mathrm{~km}$ upstream (west) of the NPI, which include atmospheric temperature, relative humidity, zonal moisture flux and meridional moisture flux at different pressure levels (Schaefer et al., 2013). The correlations between the daily averaged output of the WRF model and the statistical downscaling technique at the different grid points range between 0.65 and 0.80 for precipitation, 0.85 and 0.93 for temperature and 0.56 and 0.77 for solar radiation and indicate that the statistical downscaling is applicable.

A further downscaling of the input data of the mass balance model is realized to obtain input data with a resolution of $180 \mathrm{~m}$, the resolution used for the surface mass balance model. Temperature and precipitation are "physically interpolated" by applying constant lapse rates $\left(-0.65^{\circ} \mathrm{C} / 100 \mathrm{~m}\right.$ and $5 \% / 100 \mathrm{~m}$, respectively) and incoming solar radiation on the $180 \mathrm{~m}$ grid is computed by comparing the radiation computed for the $5 \mathrm{~km}$ grid with calculations from clear-sky radiation on the $180 \mathrm{~m}$ grid (Schaefer et al., 2013; Corripio, 2003).
In the surface mass balance model, ablation was calculated according to a simplified energy balance model (Oerlemans, 2001; Machguth et al., 2009): the net short-wave radiation was determined by the incoming solar radiation and three different albedo values for snow (0.7), firn (0.45) and ice (0.3), while the sum of the net long-wave radiation and the turbulent fluxes was approximated by a linear function of the air temperature. Since the SPI is situated in a relatively mild, maritime climate, the ice is supposed to be temperate, so we assume that ice which melts at the surface will not refreeze but immediately run off from the SPI. Accumulation at every grid cell was defined as solid precipitation, which is as a fraction of the total precipitation that varied between zero and one depending on the air temperature of the grid cell (Schaefer et al., 2013).

\section{Results and discussion}

\subsection{Climate}

The result of the downscaling process are daily maps of the surface mass balance input variables temperature, incoming solar radiation and precipitation at the resolution of the mass balance model. In Fig. 2a, we present the annual mean incoming solar radiation (averaged over 1975-2011). The radiation pattern can be divided in two main parts: the central and western part of the icefield, where yearly average 
incoming solar energy is below $70 \mathrm{~W} \mathrm{~m}^{-2}$, and the eastern part which corresponds to the lower part of the eastern outlet glaciers, where the incoming solar radiation is much higher, reaching values of up to $150 \mathrm{~W} \mathrm{~m}^{-2}$ on some glacier tongues. On the tongues of some northwestern outlet glaciers, the incoming solar radiation is also higher than in the central part of the icefield (up to $100 \mathrm{~W} \mathrm{~m}^{-2}$ ). These results of incoming solar radiation reflect well the climatic situation on the SPI, where nearly all year long clouds are blocked by the high peaks of the icefields, which reduces the incoming solar radiation. East of the high peaks, cloudiness decreases and incoming solar radiation increases. Several glacier tongues in the northwest of the icefield reach out of this permanent sea of clouds and receive more solar radiation than the center part of the icefield. The downscaled average precipitation map shows a strong increase with elevation due to the generation of orographic precipitation in the regional climate model. East from the Andes main ridge, the modeled precipitation decreases rapidly. The temperature decreases with elevation as expected. The results of the downscaling of the meteorological data was compared in detail to meteorological data (Schaefer et al., 2013). Subsequently a calibration of the surface mass balance model has been realized using mass balance measurements in the NPI. Since the climatological situation on the SPI is very similar to the NPI we use the same calibration for the SPI and present surface mass balance simulations for the set of model parameters that performed best on the NPI (Schaefer et al., 2013).

\subsection{Distributed surface mass balance}

In Fig. $2 b$ we present the distributed annual surface mass balance averaged over 1975-2011. A very positive surface mass balance of up to $20 \mathrm{~m}$ w.e. is obtained for the very high peaks of the icefield. On the flat plateau, the surface mass balance is between 0 and $5 \mathrm{~m}$ w.e. and on the outlet glacier tongues it reaches down to $-15 \mathrm{~m}$ w.e. The direct (point) observations of the surface mass balance on the SPI are restricted to a network of ablation stakes with changing configuration on the Perito Moreno glacier during 1995 and 2003 (Stuefer et al., 2007), a tower installed near the equilibrium line of the Chico glacier where yearly surface mass balance values at one point were obtained from 1994 to 2002 (Rivera, 2004) and four firn cores in the accumulation areas of the Moreno (Aristarain and Delmas, 1993), Tyndall (Shiraiwa et al., 2002), Chico (Schwikowski et al., 2006) and PioXI glaciers (Schwikowski et al., 2013). In Fig. 3 we compare the results of our simulations to these direct point measurements of the surface mass balance. Satisfactory agreement can be observed between the modeled and the measured data for the ablation data. In the accumulation area, however, in two cases the modeled accumulation is much higher than the observed one. These two points correspond to firn cores taken on high peaks in the accumulation areas of the Perito Moreno and PioXI glaciers. The probably large amounts

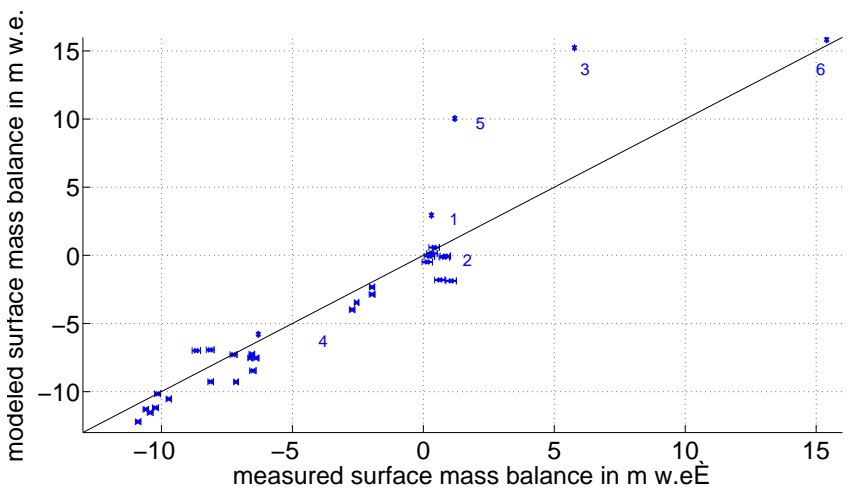

Figure 3. Comparison between measured and simulated surface mass balance: numbers correspond to places marked in Fig. 1. The values in the accumulation area are yearly accumulation values, while the ablation data are summer, winter or yearly values depending on the availability of data. The uncertainties of the measurements are indicated as error bars in the $x$ direction if available.

of snow falling at this locations do not persist on the windexposed peaks (Schwikowski et al., 2013). Indeed, some ice core drilling sites were specifically chosen to minimize accumulation compared to the surroundings, to obtain longer time series in the shallow ice cores (Schwikowski et al., 2006). The process of wind drift, however, is not incorporated in the model, which likely explains the difference between observed and modeled values. These local effects are important when comparing point measurements with modeled surface mass balance, but should have a less important role when estimating the surface mass balance of larger areas such as glacier basins or even the entire SPI, since the drifted snow will most probably contribute to the accumulation in another part of the icefield. Since the wind direction is predominantly west, the snow drift could, however, diminish the accumulation on western windward glacier basins and increase the accumulation on the eastern leeward glacier basins.

\subsection{Evolution of net mass balance values of the SPI}

The evolution of the annual accumulation, surface ablation and surface mass balance from 1975 to 2010 for the SPI as a whole are presented in Fig. 4. A high interannual variability and an increasing overall trend $(0.054 \pm 0.012 \mathrm{~m}$ w.e. $\mathrm{yr}^{-2}$ ) of the surface mass balance can be observed. Both the variability and the increasing trend is determined by the accumulation. Furthermore, maxima in accumulation (e.g., 1990, 1998, 2009) are accompanied by minima in ablation, since the higher amounts of snow present in these years reduces the albedo of SPI surface. The variation of measured yearly precipitation at the selected stations in Fig. 4 is similar to the variation of the modeled accumulation. This is a good confirmation of the model's results, considering that measured precipitation data are not direct input data of the model. The average specific melt on the SPI in 1975-2011 


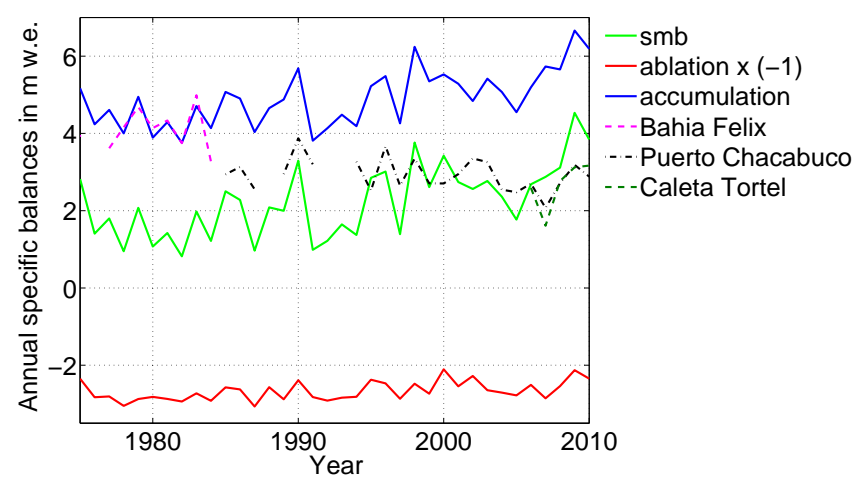

Figure 4. Annual specific accumulation, ablation and surface mass balance (smb) averaged over the SPI from 1975-2010 and yearly measured precipitation sums for selected weather stations in the region: Bahía Felix $\left(52^{\circ} 58^{\prime} \mathrm{S}, 74^{\circ} 08^{\prime} \mathrm{W}\right)$ south of the SPI, Puerto Chacabuco $\left(45^{\circ} 26^{\prime} \mathrm{S}, 72^{\circ} 49^{\prime} \mathrm{W}\right)$ north of the NPI and Caleta Tortel $\left(47^{\circ} 47^{\prime} \mathrm{S}, 73^{\circ} 32^{\prime} \mathrm{W}\right)$ between NPI and SPI.

is $2.63 \mathrm{~m}$ w.e. $\mathrm{yr}^{-1}$, and the average specific accumulation $4.87 \mathrm{~m}$ w.e. $\mathrm{yr}^{-1}$. The percentage of solid precipitation of the overall precipitation was $59 \%$, which leads to an average of $8.36 \mathrm{~m}$ of yearly precipitation over the SPI for 1975-2011. This value is $19 \%$ higher than the $7 \mathrm{~m}$ inferred by Escobar et al. (1992), analyzing water discharge data from the 1960 s to the 1980s. The higher average precipitation over the SPI obtained by our model can be explained by the increase of accumulation (caused by an increase of precipitation) in the 2000s (Fig. 4). The average modeled precipitation over SPI is slightly higher than the value of $8.03 \mathrm{~m}$ modeled for the NPI (Schaefer et al., 2013). It is expected that the total amount of precipitation over the SPI is higher than on the NPI, since wind speeds, which correlate strongly with precipitation in this region, increase to the south (Garreaud et al., 2012; Lenaerts et al., 2014).

When analyzing another important component of the mass balance of the SPI, namely mass losses due to calving, we will transform the modeled mass losses to losses in volume of ice. We can convert the modeled specific mass changes due into surface processes to changes of volume in ice $\Delta V_{\text {surf }}$ by multiplying them with the surface area of the SPI and dividing by the density of ice $\left(900 \mathrm{~kg} \mathrm{~m}^{-3}\right)$. Knowing the total volume change $\Delta V_{\text {total }}$ of the SPI from geodetic mass balance surveys (Rignot et al., 2003; Willis et al., 2012b), we can calculate the calving losses from the SPI according to

$Q_{c}=\Delta V_{\text {surf }}-\Delta V_{\text {total }}$.

For 1975-2000 we obtain an increase of ice volume due to surface processes of $27.7 \mathrm{~km}^{3} \mathrm{yr}^{-1}$. Together with the observed volume loss of $16.7 \pm 0.9 \mathrm{~km}^{3} \mathrm{yr}^{-1}$ observed for this period by Rignot et al. (2003), we obtain calving losses of $Q_{c}=44.4 \mathrm{~km}^{3} \mathrm{yr}^{-1}$. For 2000-2011 we obtain from the observed volume loss of $21.2 \pm 0.4 \mathrm{~km}^{3} \mathrm{yr}^{-1}$
(Willis et al., 2012b) and the modeled increase in volume due to surface processes of $40.1 \mathrm{~km}^{3} \mathrm{yr}^{-1}$ calving losses of $Q_{c}=61.3 \mathrm{~km}^{3} \mathrm{yr}^{-1}$. The uncertainties associated with these inferred calving fluxes from the SPI are high. It is difficult to a priori constrain the uncertainties associated with the modeled ice volume change due to surface mass balance (see Sect. 3.5), and we therefore try to learn about these uncertainties by comparing inferred calving fluxes to calving fluxes estimated from velocity measurements at the different glacier catchments (Sect. 3.6, Table 1). Also, the uncertainties associated with the geodetic balances might be higher than stated by their authors: both authors of the geodetic balances assume that all volume change is due to ice loss and therefore convert volume loss to mass loss assuming a density of $900 \mathrm{~kg} \mathrm{~m}^{-3}$. Willis et al. (2012b) details volume loss for ablation area and accumulation separately. If we assume that the volume loss in the accumulation area is due melt of firn with a density of $550 \mathrm{~kg} \mathrm{~m}^{-3}$, the corresponding ice loss would be lower and the calving fluxes would lower to $Q_{c}=56.8 \mathrm{~km}^{3} \mathrm{yr}^{-1}$. Although assuming large uncertainties on the inferred overall calving losses of SPI, we can still state that a strong increase in calving losses took place, which is supported by an acceleration of the glaciers of SPI (Jaber et al., 2012; Rivera et al., 2012a; Sakakibara et al., 2013). For comparison, the modeled yearly accumulation over the SPI for $1975-2000$ corresponds to $66.7 \mathrm{~km}^{3}$ of ice per year and $73.1 \mathrm{~km}^{3}$ of ice per year for 2000-2011, and the modeled melt from SPI is $39.0 \mathrm{~km}^{3} \mathrm{yr}^{-1}$ for $1975-2000$ and $33.0 \mathrm{~km}^{3} \mathrm{yr}^{-1}$ for $2000-2011$. This means that the inferred losses due to calving are higher than losses by melt in both periods. In all these conversions, we used the SPI reference area of $13000 \mathrm{~km}^{2}$ from Rignot et al. (2003) to convert the specific values to overall change for 1975-2000 and the area of $12100 \mathrm{~km}^{2}$ (Willis et al., 2012b) for 2000-2011.

\subsection{Surface mass balance of the individual glacier catchments}

Apart from the overall trend in the mass balance components of the SPI, it is interesting to analyze the individual glacier catchments as closed systems, to be able to quantify the different contributions of the terms of the mass balance for the different glaciers. However, due to the large flat areas on the SPI, the definition of the catchments (especially in the northern part of the SPI) is not unique and probably also changes with time (Rivera et al., 2012a). In Fig. 2c, we present the 1975-2011 average specific annual surface mass balance of the individual glaciers using the catchments defined in the Randolph Glacier Inventory (RGI) (Arendt, 2012). In the northern part of the SPI (north of $49.5^{\circ} \mathrm{S}$ ) the main glaciers have annual glacier surface mass balances ranging from slightly negative (Chico glacier $-1.58 \mathrm{~m}$ w.e.) to clearly positive (PioXI glacier $3.45 \mathrm{~m}$ w.e.). The only exception is the Occidental glacier, having a clearly negative annual surface mass balance $(-4.85 \mathrm{~m}$ w.e.). Since this 
Table 1. 1975-2011 average altitude of zero surface mass balance (ELA) computed by the model and the average altitude of the snow line at the end of summers 2002 and 2004 computed by De Angelis (2014) (column 1 and 2). Inferred calving fluxes according to Eq. (1) using the geodetic mass balance measurements of Rignot et al. (2003) for the period 1975-2000 and of Willis et al. (2012a) for 2000-2011 (column 3 and 4). Calving fluxes based on a velocity map from spring 2004 (column 5) and explicit data used to compute these fluxes (columns 6-8). Column 9 indicates if the calving fluxes computed from the velocity field agree within one standard deviation with the inferred fluxes for 1975-2000 (R) or 2000-2011 (W) or both (RW).

\begin{tabular}{|c|c|c|c|c|c|c|c|c|c|}
\hline Glacier & $\begin{array}{c}\text { ELA (m) } \\
1975-2011\end{array}$ & $\begin{array}{c}\text { SLA (m) } \\
\text { De Angelis } 2014\end{array}$ & $\begin{array}{c}Q_{c} \text { Inferred } \\
1975-2000 \\
\left(\mathrm{~km}^{3} \mathrm{yr}^{-1}\right)\end{array}$ & $\begin{array}{l}Q_{c} \text { Inferred } \\
2000-2011 \\
\left(\mathrm{~km}^{3} \mathrm{yr}^{-1}\right)\end{array}$ & $\begin{array}{c}Q_{c} \\
\text { from velocities } \\
\text { spring } 2004 \\
\left(\mathrm{~km}^{3} \mathrm{yr}^{-1}\right)\end{array}$ & $\begin{array}{l}W_{\text {tot }} \\
(\mathrm{km})\end{array}$ & $\begin{array}{c}\bar{V} \\
\left(\mathrm{~km} \mathrm{yr}^{-1}\right)\end{array}$ & $\begin{array}{c}\bar{H} \\
(\mathrm{~m})\end{array}$ & $\begin{array}{c}\text { Agreement } \\
\text { within } \\
1 \sigma\end{array}$ \\
\hline Amalia & 861 & $930 \pm 40$ & $0.78 \pm 0.05$ & $(0.92-0.96) \pm 0.07$ & $0.42 \pm 0.35$ & 2.45 & 0.57 & $300 \pm 250$ & $\mathrm{R}$ \\
\hline Asia & 918 & $800 \pm 20$ & $0.32 \pm 0.03$ & $(0.48-0.50) \pm 0.05$ & $0.26 \pm 0.21$ & 0.85 & 1.00 & $300 \pm 250$ & RW \\
\hline BGOT & 1068 & $945 \pm 30$ & $1.54 \pm 0.18$ & $(1.72-2.12) \pm 0.18$ & $1.80 \pm 1.03$ & 12.51 & 0.48 & $300 \pm 250$ & RW \\
\hline $\mathrm{CV}$ & 1438 & $1264 \pm 24$ & $-1.00 \pm 0.24$ & $(1.86-2.25) \pm 0.09$ & $0.36 \pm 0.30$ & 1.97 & 0.41 & $230 \pm 180$ & - \\
\hline Europa & 995 & $940 \pm 30$ & no data & $(2.75-2.81) \pm 0.08$ & $0.41 \pm 0.34$ & 0.92 & $1.48^{*}$ & $300 \pm 250$ & - \\
\hline Grey & 1021 & $980 \pm 50$ & $1.33 \pm 0.05$ & $(1.51-1.55) \pm 0.10$ & $0.39 \pm 0.32$ & 2.17 & 0.47 & $300 \pm 250$ & - \\
\hline HPS12 & 983 & $1150 \pm 30$ & no data & $(1.38-1.43) \pm 0.05$ & $0.55 \pm 0.46$ & 0.80 & $2.29^{*}$ & $300 \pm 250$ & - \\
\hline HPS13 & 967 & $1140 \pm 60$ & no data & $(1.37-1.38) \pm 0.04$ & $1.07 \pm 0.89$ & 0.94 & $3.80^{*}$ & $300 \pm 250$ & $\mathrm{~W}$ \\
\hline HPS 15 & 928 & $950 \pm 50$ & no data & $(0.85-0.88) \pm 0.04$ & $0.55 \pm 0.46$ & 0.92 & $2.00^{*}$ & $300 \pm 250$ & $\mathrm{~W}$ \\
\hline HPS19 & 981 & $1070 \pm 60$ & no data & $(1.37-1.42) \pm 0.06$ & $0.43 \pm 0.36$ & 0.75 & $1.93^{*}$ & $300 \pm 250$ & - \\
\hline HPS29 & 951 & $1170 \pm 70$ & $0.47 \pm 0.02$ & $(0.57-0.60) \pm 0.05$ & $0.52 \pm 0.43$ & 1.22 & 1.41 & $300 \pm 250$ & RW \\
\hline HPS31 & 951 & $990 \pm 51$ & $1.07 \pm 0.03$ & $(1.04-1.08) \pm 0.06$ & $0.41 \pm 0.34$ & 0.75 & $1.80^{*}$ & $300 \pm 250$ & - \\
\hline HPS34 & 869 & $1240 \pm 100$ & $1.32 \pm 0.03$ & $(1.66-1.72) \pm 0.06$ & $0.85 \pm 0.71$ & 1.89 & $1.50^{*}$ & $300 \pm 250$ & RW \\
\hline Jorge Montt & 1112 & $930 \pm 40$ & $1.96 \pm 0.10$ & $(1.43-1.58) \pm 0.06$ & $1.20 \pm 0.54$ & 2.10 & 2.59 & $220 \pm 50$ & $\mathrm{~W}$ \\
\hline O'Higgins & 1282 & $1200 \pm 20$ & $2.15 \pm 0.15$ & $(2.97-3.27) \pm 0.13$ & $1.78 \pm 0.52$ & 2.33 & 2.25 & $340 \pm 100$ & $\mathrm{R}$ \\
\hline Penguin & 955 & $1070 \pm 70$ & no data & $(4.61-4.72) \pm 0.08$ & $0.83 \pm 0.69$ & 1.20 & $2.30^{*}$ & $300 \pm 250$ & - \\
\hline Perito Moreno & 1150 & $1230 \pm 40$ & $0.99 \pm 0.04$ & $(1.44-1.57) \pm 0.08$ & $0.44 \pm 0.16$ & 4.90 & 0.65 & $140 \pm 50$ & - \\
\hline Pío XI & 1055 & $930 \pm 50$ & $3.69 \pm 0.32$ & $(5.99-6.35) \pm 0.14$ & $2.69 \pm 1.71$ & 9.82 & $1.74^{*}$ & $200 \pm 100$ & $\mathrm{R}$ \\
\hline Tyndall & 899 & $940 \pm 10$ & $0.83 \pm 0.06$ & $(1.58-1.69) \pm 0.11$ & $0.14 \pm 0.08$ & 2.28 & 0.35 & $181 \pm 100$ & - \\
\hline Upsala & 1249 & $1170 \pm 30$ & $1.75 \pm 0.17$ & $(4.67-5.05) \pm 0.08$ & $2.41 \pm 0.40$ & 2.64 & 1.52 & $540 \pm 100$ & $\mathrm{R}$ \\
\hline
\end{tabular}

* Velocity data that were taken from a point farther than $1 \mathrm{~km}$ upstream of the glacier front.

glacier does not show an exceptional retreat or thinning behavior (López et al., 2010; Willis et al., 2012b), we think that the exceptionally negative glacier surface mass balance is caused by an erroneous delineation of glacier catchments where parts of the glacier's accumulation area were considered as belonging to neighboring glaciers. The PioXI glacier has the most positive annual surface mass balance in the area, which agrees with the advance of the glacier observed until recently (Rivera et al., 1997). In the middle-southern part of the SPI (between 49.5 and $50.5^{\circ} \mathrm{S}$ ), the annual surface mass balance of the western glaciers are very positive (up to $10.0 \mathrm{~m}$ w.e. for glacier HPS13) and moderately positive for the eastern glaciers. The very positive modeled surface mass balance of the western glaciers agrees with the accumulation area ratios of $>0.8$ observed at these glaciers (Aniya et al., 1996; Casassa et al., 2013). At the periphery of the SPI, several small glaciers can be spotted in Fig. 2c which often exhibit negative surface mass balance, which is in good agreement with the high relative area loss observed at these glaciers (Davies and Glasser, 2012).

A characteristic parameter of a glacier is the altitude at which accumulation and ablation are of same magnitude, the equilibrium line altitude (ELA). We present 1975-2011 averaged ELAs computed by the model in Table 1. For comparison we also present the average snow line altitude (SLA) at the end of the summers 2002 and 2004 computed recently by De Angelis (2014). For several glaciers (Amalia, Europa, Grey, HPS15, HPS19, HPS31, Penguin, Perito Moreno) the model ELAs agree with the average SLA at the end of the summers 2002 and 2004 within two $\sigma$. At the glaciers Asia, BGOT, CV, O'Higgins, Pío XI, Upsala and Jorge Montt the average model ELA is higher than the average SLA at the end of the summers 2002 and 2004. This discrepancy can be explained by the possibility of snowfalls before the acquisition of the examined satellite images and by the high interannual variability of the surface mass balance (Fig. 4). This idea is supported by the observation of an SLA at the end of the summer 1986 of $1300 \mathrm{~m}$ at the O'Higgins glacier (Aniya et al., 1996), which is even higher than the model average ELA. The model ELAs are considerably lower than the average SLA at the end of the summers 2002 and 2004 for the glaciers HPS12, HPS13, HPS29 and HPS34. This could also be due to the interannual variability of the surface mass balance; however, since the SLA at the end of the summer tends to underestimate the ELA rather than to overestimate it (due to possible snowfalls on the SPI during the whole year), this could also indicate a local overestimation of the surface mass balance by the model at these glaciers. At HPS34 the SLA at the end of the summer 1986 of $900 \mathrm{~m}$ (Aniya et al., 
1996), agrees much better with the average model ELA than the SLA computed by De Angelis (2014).

\subsection{Sources of uncertainties for the modeled surface mass balance}

We want to point out that our surface mass balance modeling approach is subject to different uncertainties, which are difficult to quantify in a systematic way. Several reanalysis data sets were suspected to have spurious increases in precipitation at high southern latitudes due to the inclusions of new data sets (Nicolas and Bromwich, 2011). Regional climate models still have problems with correctly quantifying orographic precipitation, which was the reason why we had to apply a global correction factor to the precipitation data (Schaefer et al., 2013). This factor could vary spatially and temporally. Also, no direct air temperature data from the icefield itself were available to validate the modeled temperatures. The acquisition of climate data on the icefield itself would be very valuable to be able to better constrain the uncertainties of the model results.

\subsection{Calving losses of the individual glaciers}

In addition to mass losses due to surface melt, nearly all major outlet glaciers of the SPI have additional mass losses due to calving (Warren and Aniya, 1999), which makes the total mass balance of the glaciers negative. Calving fluxes $Q_{c}$ can be inferred for the individual catchments using Eq. (1) again. In Table 1 we present the inferred calving fluxes in 1975-2000 and 2000-2011 for the most important outlet glaciers of the SPI. Since the ice divides in the flat parts of the SPI are difficult to determine, in Table 1 we present the Bernardo, Greve, Occidental and Tempano glaciers in the north of the SPI as one glacier (BGOT). We did the same for the Chico and Viedma (CV) glaciers which share the glacier plain around the Paso de los Cuatro glaciers. The errors indicated for the inferred calving fluxes presented in Table 1 are the inherited (quantifiable) uncertainties of the geodetic measurements. They should not be interpreted as the total uncertainty of the inferred fluxes, since the (unknown) uncertainties of the model results are not included. For calving fluxes inferred for 2000-2011, we present a range, which is obtained by converting the volume loss in the accumulation area detected by Willis et al. (2012b) to mass loss, using the density of firn $\left(550 \mathrm{~kg} \mathrm{~m}^{-3}\right)$ as the lower limit and the density of ice $\left(900 \mathrm{~kg} \mathrm{~m}^{-3}\right)$ as the upper limit.

To validate the inferred calving fluxes, we computed calving fluxes from a complete velocity field of the SPI obtained from a speckle-tracking analysis of RADARSAT-1 images from September to November 2004. For every glacier we computed the average velocity at the front $\bar{V}$ and derived calving flux from the width at the front $W, \bar{V}$ and the average ice thickness at the front $\bar{H}$. The latter, however, was mostly unknown. Bathymetric measurements of the water bodies in which the glaciers are calving were available for the glaciers Jorge Montt (Rivera et al., 2012b), O'Higgins (unpublished data), Perito Moreno (Rott et al., 1998), Upsala (Skvarca et al., 2003), PioXI (Warren and Rivera, 1994) and Tyndall (Raymond et al., 2005), which provided a good constraint to the ice thickness at the front. There are bathymetric measurements from the Chilean Navy Hydrographic and Oceanographic Service (SHOA) in many Patagonian fjords as well, but mostly they do not extend towards the glacier fronts. In Fig. 1 we present some point measurements from SHOA. Therefore, for most of the other glaciers, an ice thickness of $300 \pm 250 \mathrm{~m}$ was assumed, which means that we assign a $68 \%$ probability to the event that at an arbitrary calving glacier tongue of the SPI has an ice thickness between 50 and $550 \mathrm{~m}$. This is supported by our experience that calving glaciers of similar size normally have ice cliffs of $50 \mathrm{~m}$ and larger and are normally not able to persist in water bodies of depth greater than $500 \mathrm{~m}$. For the Chico glacier we estimated $\bar{H}=100 \pm 50 \mathrm{~m}$. Calving fluxes were computed according to $Q_{c}=\bar{V} \cdot \bar{H} \cdot W$, where the products were obtained for every tongue and summed up in the case of several tongues (BGOT for example). The obtained calving fluxes, together with the explicit data for mean velocity, tongue width and estimated ice thickness are presented in Table 1 as well. The uncertainties of the calving fluxes estimated from the velocity field are dominated by the uncertainties of the ice thickness.

The comparison of the inferred calving fluxes with the calving fluxes computed from the velocity field in spring 2004 shows that the inferred calving fluxes are systematically higher. One immediate explanation for this is the fact that at the glacier fronts the method of speckle-tracking analysis of RADARSAT-1 images does not work very well due to the loss of coherence induced by fast ice deformation which changes the characteristic patterns of the glacier over the 24day cycles of the satellite. Therefore the data presented in Table 1 do not always correspond to the glacier's velocity right at the glacier front. Since calving glaciers normally show high shear rates at the glacier fronts, for example the San Rafael glacier (Willis et al. (2012a)), this leads to an underestimation of the calving flux. This might explain the discrepancy between inferred calving fluxes and the calving fluxes estimated from the velocity measurements for the glaciers Europa, HPS12, HPS19 and Penguin, where clearly higher velocity has been registered for the period 2005-2011 using cross-correlation techniques with satellite images (M. Willis, personal communication, September 2014).

Not very coherent data on calving fluxes could be inferred for the CV glacier complex. In 1975-2000, Rignot et al. (2003) detected very low thinning $(0.01 \pm 0.25 \mathrm{~m}$ w.e. $)$, while the model is producing a negative glacier surface balance, which produces the negative calving fluxes. We think that in this case, Rignot et al. (2003) underestimated the thinning of the glacier, since it contradicts the considerable area loss and retreat of the glacier detected during 1986-2001 (Davies and Glasser, 2012; White and Copland, 2013). Here it has 
to be noted that the annual balances for Argentinean glaciers in Rignot et al. (2003) are in reality averages over the period 1968-2000 and that the digital elevation model generated for the Argentinean glaciers in 1968 has a much lower precision than the digital elevation model of Chilean glaciers from 1975. On the other hand, the high thinning observed in 2000-2011 seems to disagree with the moderate calving estimated from the velocity data. However newer velocity data from the Viedma glacier (Riveros et al., 2013) indicate front velocities 3 times higher than our data, which would bring the calving flux estimation into better agreement with the inferred fluxes for 2000-2011.

For the glaciers Moreno, Grey and Tyndall the velocity data from the speckle-tracking analysis of RADARSAT-1 images are available at the front of the glaciers. And for the Perito Moreno glacier, similar velocity data were obtained before and after 2004 (Rott et al., 1998; Ciappa et al., 2010). Still, the inferred calving fluxes are much higher than the ones estimated from the velocity data. According to Eq. (1), this disagreement could be due to a local overestimation of the modeled surface mass balance or an overestimation of the volume losses by the geodetic mass balances. Since the thinning observed in the geodetic mass balances (Rignot et al., 2003; Willis et al., 2012b) at the Perito Moreno glacier contradicts its stable behavior with even some advances observed during the end of the 20th century and the beginning of the 21st century, we computed calving fluxes assuming a total glacier mass balance of zero at the Perito Moreno glacier. In this case we would obtain $Q_{c}=0.78 \mathrm{~km}^{3} \mathrm{yr}^{-1}$ for 1975-2000 and $Q_{c}=1.10 \mathrm{~km}^{3} \mathrm{yr}^{-1}$ for 2000-2011. These inferred calving fluxes are still clearly higher than the ones estimated from velocity data, and we therefore examine the modeled surface mass balance at the Perito Moreno glacier in more detail.

\subsection{Mass balance of the Perito Moreno glacier}

In Fig. 5 we present the modeled 1975-2011 average specific surface mass balance as it varies with altitude. In the same graph, we present the specific surface mass balance profile obtained by Stuefer et al. (2007) for the balance year 1999/2000 using a degree-day model calibrated with stake measurements in the ablation zone between 1995 and 2003 and precipitation data from a precipitation climatology which was extrapolated to the glacier assuming a linear precipitation increase below the ELA and a precipitation increase determined by a curve which asymptotically approached a maximum precipitation value at an elevation of $2500 \mathrm{~m}$ above the ELA. This maximum precipitation value was adjusted to obtain an overall mass balance of zero of the glacier. Furthermore, we show the specific surface mass balance profile obtained by De Angelis (2014) using a degree-day model for ablation as well and stochastically modeled precipitation, which was also constrained by an inferred total accumulation value. Furthermore we show a bilinear profile obtained by

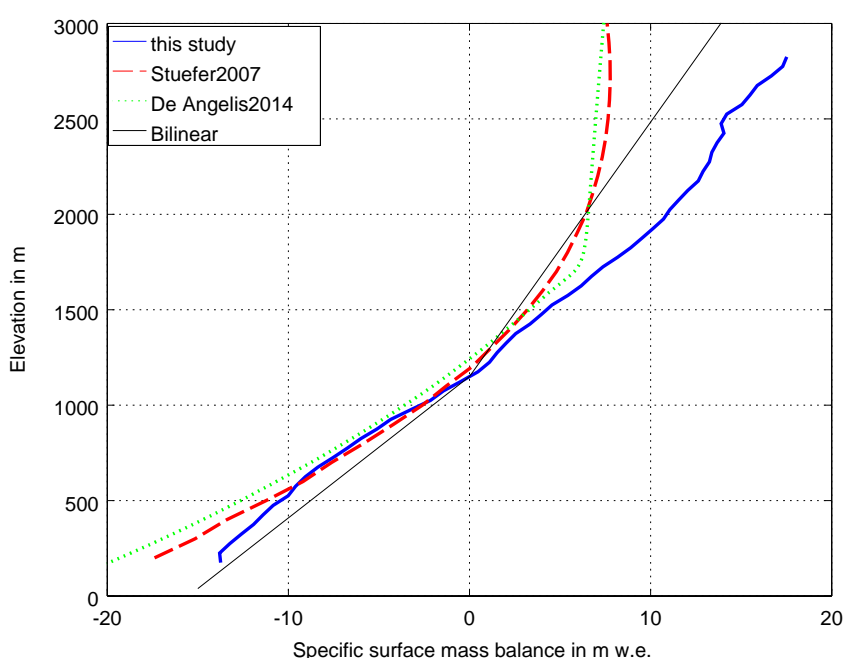

Figure 5. Specific surface mass balance profiles for Perito Moreno glacier obtained from this study (blue), Stuefer et al. (2007) (reddashed) and De Angelis (2014) (green dotted). Theoretical bilinear profile for comparison.

assuming a constant specific surface mass balance gradient of $0.0135 \mathrm{~m}$ w.e. $\mathrm{m}^{-1}$ in the ablation zone and of $0.0075 \mathrm{~m}$ w.e. $\mathrm{m}^{-1}$ in the accumulation zone. The profiles agree relatively well in the ablation zone. The profiles of De Angelis (2014) and Stuefer et al. (2007) have a slightly lower specific surface mass balance at lower elevations. In the accumulation zone, the profiles show strong differences. Stuefer et al. (2007) assumed an upper limit $7.6 \mathrm{~m}$ of precipitation which constrains the accumulation above 2500 m elevation. De Angelis (2014) obtained a very pronounced kink in the specific surface mass balance profile at an elevation of $1700 \mathrm{~m}$. The bilinear profile, by definition, has a kink at the ELA, while in our modeled profile the specific surface mass balance continues to increase with altitude in the accumulation area at a similar rate as in the ablation area. The consequence of this strong increase is a very high specific surface mass balance of around $17.5 \mathrm{~m}$ w.e. at an elevation of $2800 \mathrm{~m}$. This high gradient of the surface mass balance in the accumulation area is producing an elevated surface mass balance for the entire glacier which causes the overestimation of the calving fluxes when applying Eq. (1). Since the accumulation which determines the specific surface mass balance profile above the ELA was tuned by the other two studies (De Angelis (2014) and Stuefer et al. (2007)) to match the overall observed zero mass balance of the glacier, their profiles probably quantify better the surface mass balance at higher altitudes. However, without having spatially distributed accumulation measurements at our disposal, we can not judge which of the specific surface mass balance profiles quantifies best the accumulation on the Perito Moreno glacier.

Another explanation for a local overestimation of the calving fluxes computed by Eq. (1) could be the existence of an 
additional process of mass loss which is not accounted for in the equation. Since there are four active volcanoes that coincide with the southern part of the SPI (see Fig. 1), volcanic activity could induce sub-glacial melt which would lower the mass balance of the glaciers and possibly explain the discrepancy between inferred calving fluxes and measured ones. However, assuming a high constant geothermal heat flow of $1000 \mathrm{~mW} \mathrm{~m}^{-2}$ (mean heat flow over the continental crust is $65 \mathrm{~mW} \mathrm{~m}^{-2}$ ) would only lower the specific mass balance by $0.09 \mathrm{~m}$ w.e. On a glacier like Perito Moreno, for example, this would only cause an additional mass loss of $0.03 \mathrm{~km}^{3}$, a very low value compared to the high mass turnover of the glacier and the large uncertainties concerning the calving fluxes.

\section{Conclusions}

In this contribution we present a first quantification of mass balance processes for the Southern Patagonia Icefield. We conclude that the surface mass balance of the SPI is positive and that it was increasing during 1975-2011. The increase and the variability of the modeled surface mass balance was determined by the accumulation which was $67.7 \mathrm{~km}^{3}$ of ice per year on average in 1975-2011. The modeled average surface melt was $36.5 \mathrm{~km}^{3}$ of ice per year and showed good agreement with sparse data from stakes. Using overall balances from geodetic mass balance surveys, calving fluxes could be inferred from the modeled surface mass balance. The inferred losses due to calving showed a strong increase from $44.4 \mathrm{~km}^{3}$ (1975-2000) to $61.3 \mathrm{~km}^{3}$ ice per year (20002011). In both cases they were higher than losses due to melt of snow and ice $\left(39 \mathrm{~km}^{3}\right.$ of ice per year for $1975-2000$ and $33 \mathrm{~km}^{3}$ for 2000-2011). Since due to scarcity of validation data the uncertainties of the modeled surface mass balance are difficult to constrain, the uncertainties of these numbers are relatively high. Additionally, geodetic mass balance surveys are subject to important uncertainties, because of the often unknown density in the accumulation area of the glaciers. Assigning a density of $550 \mathrm{~kg} \mathrm{~m}^{-3}$ (instead of $900 \mathrm{~kg} \mathrm{~m}^{-3}$ ) to the mass loss in the accumulation area of SPI, for example, would lower the inferred calving fluxes in 2000-2011 to $56.8 \mathrm{~km}^{3} \mathrm{yr}^{-1}$.

Comparison of the inferred calving fluxes of the most important outlet glaciers with calving fluxes estimated from a velocity field obtained in spring 2004 showed satisfactory agreement for several glaciers. However, the uncertainties of the calving fluxes estimated from the velocity data are large, due to the mostly unknown ice thickness at the glaciers' fronts. On some glaciers the inferred calving fluxes overestimate the losses due to calving. Therefore, the inferred overall calving fluxes should be better interpreted as an upperboundary estimate.

Long-term velocity measurements and ice-thickness measurements at the calving front of the glaciers are necessary to better constrain the calving losses from the SPI, which would help significantly to reduce the uncertainties of surface mass balance reconstructions as well. Ablation measurements at more glaciers (especially at the western side of the SPI) could help to better judge the performance of surface mass balance models on the SPI. Since precipitation is one of the most uncertain outputs of regional climate models, spatially distributed accumulation measurements could help to better judge the performance of these models. Appropriate sites for accumulation measurements are smooth and rather flat areas in the central plateau of the accumulation area of the glaciers at elevations of about $1500 \mathrm{~m}$ a.s.l. and not wind exposed peaks and ridges where snow drift dominates the accumulation patterns.

Author contributions. M. Schaefer, H. Machguth and G. Casassa designed the overall research, M. Falvey ran the regional climate model and did the statistical downscaling, M. Schaefer ran the surface mass balance code and wrote the manuscript, E. Rignot provided the velocity data and all authors commented on the manuscript.

Acknowledgements. The authors would like to thank the Chilean Weather Service (DMC) and the Chilean Water Directory (DGA) for providing meteorological data, Andres Rivera for sharing the data of his $\mathrm{PhD}$ thesis, Mike Willis for sharing the glacier outlines used in his work and anticipating his unpublished velocity data, Hernán De Angelis and Martin Stuefer for sharing their mass balance profile data electronically and the Chilean Navy Hydrographic and Oceanographic Service (SHOA) for providing bathymetric data for the Patagonian fjords. We would like to thank Mauricio Pelto, Helmut Rott and an anonymous reviewer, whose comments helped to significantly improve the manuscript. M. Schaefer is FONDECYT Postdoc Fellow (project no. 3140135). This work was partly supported by funding from the ice 2 sea programme from the European Union 7th Framework Programme, grant no. 226375. Ice2sea contribution no. 168.

Edited by: J. L. Bamber

\section{References}

Aniya, M., Sato, H., Naruse, R., Skvarca, P., and Casassa, G.: The Use of Satellite and Airborne Imagery to Inventory Outlet Glaciers of the Southern Patagonia Icefield, South America, Photogramm. Eng. Rem. S., 62, 1361-1369, 1996.

Aravena, J.-C. and Luckman, B. H.: Spatio-temporal rainfall patterns in Southern South America, Int. J. Climatol., 29, 21062120, doi:10.1002/joc.1761, 2009.

Arendt, E. A.: Randolph Glacier Inventory [v3.0]: A Dataset of Global Glacier Outlines, Tech. rep., Global Land Ice Measurements from Space, Boulder Colorado, USA, 2012.

Aristarain, A. and Delmas, R.: Firn-core study from the Southern Patagonia Ice Cap, South America, J. Glaciol., 39, 249-254, 1993. 
Carrasco, J., Casassa, G., and Rivera, A.: Meteorological and Climatological aspects of the Southern Patagonia Icefield, in: The Patagonian Icefields A Unique Natural Laboratory for Environmental and Climate Change Studies, Kluwer Academic/Plenum Publishers, New York, 29-41, 2002.

Casassa, G., Rodríguez, J. L., and Loriaux, T.: A new glacier inventory for the Southern Patagonia Icefield and areal changes 19862000, Chapter 27 in Global Land Ice Measurements from Space, Springer Praxis Books, 2013.

Ciappa, A., Pietranera, L., and Battazza, F.: Perito Moreno Glacier (Argentina) flow estimation by COSMO SkyMed sequence of high-resolution SAR-X imagery, Remote Sens. Environ., 114, 2088-2096, 2010.

Corripio, J.: Vectorial algebra algorithms for calculating terrain parameters from DEMs and solar radiation modelling in mountainous terrain, Int. J. Geogr. Inf. Sci., 17, 1-23, doi:10.1080/713811744, 2003.

Davies, B. J. and Glasser, N.: Accelerating shrinkage of Patagonian glaciers from the Little Ice Age (AD 1870) to 2011, J. Glaciol., 58, 1063-1084, doi:10.3189/2012JoG12J026, 2012.

De Angelis, H.: Hypsometry and sensitivity of the mass balance to changes in equilibrium-linr altitude: the case of the Southern Patagonia Icefield, J. Glaciol., 60, 14-28, 2014.

Escobar, F., Vidal, F., Garin, C., and Naruse, R.: Water balance in the Patagonia Icefield, in: Glaciological Researches in Patagonia 1990, edited by: Naruse, R. and Aniya, M., Nagoya: Japanese Society of Snow and Ice, 109-119. 1992.

Falvey, M. and Garreaud, R. D.: Regional cooling in a warming world: Recent temperature trends in the southeast Pacific and along the west coast of subtropical South America (1979-2006), J. Geophys. Res., 114, D04102, doi:10.1029/2008JD010519, 2009.

Fowler, H. J., Blenkinsop, S., and Tebaldib, C.: Linking climate change modelling to impacts studies: recent advances in downscaling techniques for hydrological modelling, Int. J. Climatol., 27, 1547-1578, 2007.

Garreaud, R., Lopez, P., Minvielle, M., and Rojas, M.: Large Scale Control on the Patagonia Climate, J. Climate, 26, 215-230, 2012.

Ibarzabal y Donangelo, T., Hoffmann, J., and Naruse, R.: Recent climate changes in southern Patagonia, B. Glacier Res., 14, 2936, 1996.

Jaber, W. A., Floricioiu, D., Rott, H., and Eineder, M.: Dynamics of fast glaciers in the Patagonia Icefields derived from Terrasar-X and Tandem-X data, in: Geoscience and Remote Sensing Symposium (IGARSS), 2012 IEEE International, 2012.

Kalnay, E., Kanamitsu, M., Kistler, R., Collins, W., Deaven, D., Gandin, L., Iredell, M., Saha, S., White, G., Woollen, J., Zhu, Y., Chelliah, M., Ebisuzaki, W., Higgins, W., Janowiak, J., Mo, K., Ropelewski, C., Wang, J., Leetmaa, A., Reynolds, R., Jenne, R., and Joseph, D.: The NCEP/NCAR 40-year reanalysis project, B. Am. Meteorol. Soc., 77, 437-471, doi:10.1175/15200477(1996)077<0437:TNYRP>2.0.CO;2, 1996.

Lenaerts, J. T. M., van den Broeke, M. R., van Wessem, J. M., van de Berg, W. J., van Meijgaard, E., van Ulft Lambertus H, and Schaefer, M.: Extreme Precipitation and Climate Gradients in Patagonia Revealed by High-Resolution Regional Atmospheric Climate Modeling, J. Climate, 27, 4607-4621, 2014.

López, P., Chevallier, P., Favier, V., Pouyaud, B., Ordenes, F., and Oerlemans, J.: A regional view of fluctuations in glacier length in southern South America, Global Planet. Change, 71, 85-108, 2010.

Machguth, H., Paul, F., Kotlarski, S., and Hoelzle, M.: Calculating distributed glacier mass balance for the Swiss Alps from regional climate model output: A methodical description and interpretation of the results, J. Geophys. Res.-Atmos., 114, D19106, doi:10.1029/2009JD011775, 2009.

Masiokas, M. H., Rivera, A., Espizua, L. E., Villalba, R., Delgado, S., and Carlos Aravena, J.: Glacier fluctuations in extratropical South America during the past 1000 years, Palaeogeogr. Palaeocl., 281, 242-268, doi:10.1016/j.palaeo.2009.08.006, 2009.

Nicolas, J. and Bromwich, D.: Precipitation Changes in High Souther Latitudes from Global Reanalyses: A Cautionary Tale, Surv. Geophys., 32, 475-494, 2011.

Oerlemans, J.: Glaciers and Climate Change, A. A. Balkema Publishers, Lisse, Abingdon, Exton, Tokyo, 2001.

Orihashi, Y., Naranjo, J., Motoki, A., Sumino, H., Hirata, D., Anma, R., and Nagao, K.: The Quaternary volcanic activity of Hudson and lautaro volcanoes, Chilean Patagonia: new age constraints from K-Ar ages, Revista Geológica de Chile, 31, 207-224, 2004.

Rasmussen, L. A., Conway, H., and Raymond, C. F.: Influence of upper air conditions on the Patagonia icefields, Global Planet. Change, 59, 203-216, doi:10.1016/j.gloplacha.2006.11.025, 2007.

Raymond, C., Neumann, T., Rignot, E., Echelmeyer, K., Rivera, A., and Casassa, G.: Retreat of Glaciar Tyndall, Patagonia, over the last half-century, J. Glaciol., 51, 239-247, doi:10.3189/172756505781829476, 2005.

Rignot, E., Rivera, A., and Casassa, G.: Contribution of the Patagonia Icefields of South America to sea level rise, Science, 302, 434-437, doi:10.1126/science.1087393, 2003.

Rivera, A.: Mass balance investigations at Glaciar Chico, Southern Patagonia Icefield, Chile, PhD thesis, University of Bristol, UK, 2004.

Rivera, A., Lange, H., Aravena, J., and Casassa, G.: The 20thcentury advance of Glaciar Pio XI, Chilean Patagonia, Ann. Glaciol., 24, 66-71, 1997.

Rivera, A., Corripio, J., Bravo, C., and Cisternas, S.: Glaciar Jorge Montt (Chilean Patagonia) dynamics derived from photos obtained by fixed camera and satellite image feature tracking, Ann. Glaciol., 53, 147-155, 2012a.

Rivera, A., Koppes, M., Bravo, C., and Aravena, J. C.: Little Ice Age advance and retreat of Glaciar Jorge Montt, Chilean Patagonia, Clim. Past, 8, 403-414, doi:10.5194/cp-8-403-2012, 2012.b.

Riveros, N., Euillades, L., Euillades, P., Moreiras, S., and Balbarani, S.: Offset tracking procedure applied to high resolution SAR data on Viedma Glacier, Patagonian Andes, Argentina, Adv. Geosci., 35, 7-13, doi:10.5194/adgeo-35-7-2013, 2013.

Rosenblüth, B., Casassa, G., and Fuenzalida, H.: Recent climatic changes in western Patagonia, B. Glacier Res., 13, 127-132, 1995.

Rott, H., Stuefer, M., Siegel, A., Skvarca, P., and Eckstaller, A.: Mass fluxes and dynamics of Moreno Glacier, Southern Patagonia Icefield, Geophys. Res. Lett., 25, 1407-1410, doi:10.1029/98GL00833, 1998.

Sakakibara, D., Suggiyama, S., Sawagaki, T., Marinsek, S., and Skvarca, P.: Rapid retreat, acceleration and thinning of 
Glaciar Upsala, Southern Patagonia Icefield, initiated 2008, Ann. Glaciol., 54, 131-138, 2013.

Schaefer, M., Machguth, H., Falvey, M., and Casassa, G.: Modeling past and future surface mass balance of the Northern Patagonian Icefield, J. Geophys. Res.-Earth, 118, 571-588, doi:10.1002/jgrf.20038, 2013.

Schwikowski, M., Bruetsch, S., Casassa, G., and Rivera, A.: A potential high-elevation ice-core site at Hielo Patagónico Sur, Ann. Glaciol., 43, 8-13, doi:10.3189/172756406781812014, 2006.

Schwikowski, M., Schläppi, M., Santibañez, P., Rivera, A., and Casassa, G.: Net accumulation rates derived from ice core stable isotope records of Pío XI glacier, Southern Patagonia Icefield, The Cryosphere, 7, 1635-1644, doi:10.5194/tc-7-16352013, 2013.

Shiraiwa, T., Kohshima, S., Uemura, R., Yoshida, N., Matoba, S., Uetake, J., and Godoi, M.: High net accumulation rates at Campo de Hielo Patagonico Sur, South America, revealed by analysis of a $45.97 \mathrm{~m}$ long ice core, Ann. Glaciol., 35, 84-90, doi:10.3189/172756402781816942, 2002.

Skvarca, P., Raup, B., and De Angelis, H.: Recent behaviour of Glaciar Upsala, a fast-flowing calving glacier in Lago Argentino, southern Patagonia, Ann. Glaciol., 36, 184-188, doi:10.3189/172756403781816202, 2003.

Stern, C.: Active Andean volcanism: its geologic and tectonic setting, Revista Geológica de Chile, 31, 161-206, 2004.
Stern, C.: Holocene tephrochronology record of large explosive eruptions in the southernmost Patagonian Andes, B. Volcanol., 70, 435-454, 2008.

Stuefer, M., Rott, H., and Skvarca, P.: Glaciar Perito Moreno, Patagonia: climate sensitivities and glacier characteristics preceding the 2003/04 and 2005/06 damming events, J. Glaciol., 53, 3-15, 2007.

Warren, C. and Aniya, M.: The calving glaciers of southern South America, Global Planet. Change, 22, 59-77, doi:10.1016/S09218181(99)00026-0, 1999.

Warren, C. and Rivera, A.: Non-linear climatic response of Calving Glaciers: A case study of Pio XI Glacier, Chilean Patagonia, Revista Chilena de Historia Natural, 67, 385-394, 1994.

White, A. and Copland, L.: Spatial and temporal variations of glacier extent across the Southern Patagonian Icefield since the 1970s, The Cryosphere Discuss., 7, 1-34, doi:10.5194/tcd-7-12013, 2013.

Willis, M. J., Melkonian, K., Pritchard, M., and Ramage, J.: Ice loss rates at the Northern Patagonian Icefield derived using a decade of satellite remote sensing, Remote Sens. Environ., 117, 184198, 2012a.

Willis, M. J., Melkonian, K., Pritchard, M., and Rivera, A.: Ice loss from the Southern Patagonian Ice Field, South America, between 2000 and 2012, Geophys. Res. Lett., 39, L17501, 2012 b. 